\title{
Slovenian Parents' Views on Emergency Remote Schooling during the First Wave of the Covid-19 Pandemic
}

Melita PukleK LeVPuščEK ${ }^{\star_{1}}$ AND LuKa URŠIČ²

$\approx$ In early 2020, the whole world was confronted with the emergence of the new SARS-CoV-2 virus. Due to restrictive measures, Slovenia, like most other countries, was forced to close all educational institutions. Teaching and learning shifted from classrooms to an online environment, which was a major challenge for teachers, students and their parents and required a significant amount of adaptation and effort. In May 2020, we conducted a study to investigate parents' attitudes toward emergency remote schooling. The study included 313 parents of students from the last triad of primary (compulsory) school (Grades 7-9; 12-15 years old), 147 parents of secondary school students (Years $1-3 ; 15-18$ years old) and 35 parents of students in their final (4th) year of secondary school (18-19 years old). Specifically, parents of primary school adolescent children, in particular, reported having the most difficulty coordinating their work and the remote schooling of their child, and they also reported more difficulty motivating their child to complete schoolwork at home than the other two groups of parents did. Parents of secondary school students in Year 4 were most likely to miss personal contact with the teacher and rated emergency remote schooling as more stressful than the other two groups of parents. In general, parents rated emergency remote schooling to be more complicated and difficult than traditional classroom instruction. Most parents agree that such schooling provides students with less knowledge, which is also less consolidated, although they perceived teachers' remote help for students quite positively. They also believe that online education will become important in the future.

Keywords: emergency remote schooling, parents, attitudes, Covid-19, pandemic

$1{ }^{\star}$ Corresponding Author. Faculty of Arts, University of Ljubljana, Slovenia; melita.puklek@ff.uni-lj.si.

2 Primary School Šmartno pod Šmarno goro Ljubljana, Slovenia. 


\section{Perspektiva slovenskih staršev o izobraževanju na daljavo v izrednih razmerah med prvim valom pandemije covida-19}

Melita Puklek LevpuščEK In Luka URŠič

$\propto$ V začetku leta 2020 se je ves svet srečal s pojavom pandemije zaradi novega virusa SARS-CoV-2. Zaradi ukrepov za zajezitev širjenja okužb je bila Slovenija, tako kot večina drugih držav, primorana zapreti vse izobraževalne ustanove. Poučevanje in učenje sta se iz učilnic premaknila v spletno okolje, kar je bil velik izziv za učitelje, učence in za njihove starše ter je od vseh deležnikov zahteval veliko prilagajanja in truda. Maja 2020 smo izvedli raziskavo, s katero smo želeli preučiti odnos staršev do izobraževanja na daljavo $\mathrm{v}$ izrednih razmerah. $\mathrm{V}$ raziskavo je bilo vključenih 313 staršev učencev zadnjega vzgojno-izobraževalnega obdobja osnovne šole, 147 staršev dijakov od prvega do tretjega letnika srednje šole in 35 staršev dijakov zaključnega (četrtega) letnika srednje šole. Starši osnovnošolcev so poročali, da imajo največ težav pri usklajevanju med službo in šolanjem otroka, prav tako so pogosteje poročali o težavah pri motiviranju otroka za šolsko delo doma kot drugi dve skupini staršev. Starši srednješolcev zaključnega letnika (maturantov) so najbolj pogrešali osebni stik $z$ učiteljem in izobraževanje na daljavo ocenili kot bolj stresno kot drugi dve skupini staršev. Na splošno so starši ocenili, da je izobraževanje na daljavo zapletenejše in težavnejše od tradicionalnega pouka v razredu. Večina staršev se je strinjala, da so šolarji med izobraževanjem na daljavo pridobili manj znanja in to je bilo tudi manj utrjeno. Starši so precej pozitivno ocenili učiteljevo pomoč učencem na daljavo. Prav tako so se strinjali, da bo spletno izobraževanje v prihodnosti postalo pomembno.

Ključne besede: izobraževanje na daljavo v izrednih razmerah, starši, stališča, covid-19, pandemija 


\section{Introduction}

The new coronavirus, SARS-CoV-2, first appeared in China in December 2019 and later spread worldwide rapidly. It completely changed the lives of the vast majority of people and required certain life adjustments. The World Health Organization (WHO) declared a new pandemic on March 11, 2020 (WHO, 2020). In response to the global pandemic, most countries worldwide have taken several measures to reduce the spread of new Covid-19 infections. The vast majority of countries decided to move schooling at different levels of education to online learning (Zhang et al., 2020). In many countries, schools closed in early March 2020, while in China and South Korea, emergency remote schooling 3 started as early as January 2020 (UNESCO, 2020). The closure of educational institutions has been based on findings of influenza virus transmission, as social distancing among people is required to limit its spread (Cowling et al., 2020; Jackson et al., 2016). Although research confirms the effectiveness of antiviral protection measures in slowing the transmission of infectious diseases (e.g., Auger et al., 2020; Hens et al., 2009), some authors (e.g., Viner et al., 2020) question the effectiveness of school closures during the Covid-19 pandemic. Telli Yamamoto and Altın (2020) found that education in the first wave of the Covid-19 pandemic was the second most affected area after healthcare. On April 9, 2020, UNESCO (2020) estimated that schools were closed in 193 countries worldwide by the end of March 2020, affecting 1.57 billion children and adolescents. This represents $91 \%$ of the total population of schoolchildren involved in formal education. The epidemic situation and lengthy emergency remote schooling have also affected teachers, other school staff, and parents. The reopening of educational institutions varied between countries. Several countries (e.g., Italy, Malta, Portugal) decided not to reopen their schools by the end of the 2019/20 year, and some (e.g., France, Germany, Slovenia) gradually, partially, or completely reopened them in April or May (Bregar et al., 2020). Rising infection rates led to renewed state closures in the fall and winter of 2020/21, and calls for school closures again grew louder. UNICEF (2021) reports that 'in the period between March 11, 2020 and February 2, 2021, schools have been fully closed for an average of 95 instruction days globally, which represents approximately half the time intended for classroom instruction' (p. 2).

3 Emergency remote schooling/emergency distance education must be distinguished from distance education (Hodges et al., 2020). It is only a temporary way of conducting classes that allows students to continue their education. Teachers and students cannot prepare well in advance, as it usually starts quickly and unannounced. At the same time, such education is compulsory for all involved in schooling, as long as the situation does not allow classroom teaching again. 
This article focuses on the situation in Slovenia and the experience of emergency remote schooling as perceived by Slovenian parents in the first wave of the pandemic that took place in the spring of 2020. Slovenia declared an epidemic on March 12, 2020, and the government temporarily closed kindergartens and schools from March 16, 2020. As in other countries, schools in Slovenia moved lessons to a virtual environment almost overnight, which caused them to face many problems, especially in the first few weeks. After that, teachers gradually became acquainted with new tools that enable working remotely (e.g., MS Teams, Zoom, online classrooms), and students began to get used to the new school reality. After two months of remote schooling, on May 18, 2020, the students of the first triad of primary schools and students in the fourth year of secondary school returned to the physical school environment. It must be noted that the spring months of a school year represent the time when Slovenian fourth-year secondary students prepare most intensively for the Matura (i.e., general final examination), which was conducted later in June 2020 in the same form as in previous years. On May 25, 2020, $9^{\text {th }}$-grade primary-school students returned to school, and two days later, the remaining primary school students joined them, while secondary school students (first to third years) finished the school year at home (Gov.si, 2020).

\section{Challenges of emergency remote schooling during Covid-19 pandemic}

In their study, Ferri et al. (2020) reported the technological, pedagogical, and social challenges that students have encountered during emergency distance education. Their report was based on the comments of an online discussion in May 2020, which included participants from European countries working in information and communications technology (ICT), social science and education. The attendees of the online forum agreed that technological challenges mainly include problems with Internet provision and the lack of electronic devices for remote work. Furthermore, they emphasised pedagogical challenges, such as students' and teachers' lack of digital skills, the abundance of less structured content and information on the web, students' lack of motivation for schoolwork and teachers' lack of social and cognitive presence. Finally, the most often mentioned social challenges were the lack of appropriate social interaction, adequate space for work and study and parental support.

The school closures in spring 2020 required the adaptation of learning and teaching to online learning environments by using ICT, such as personal computers, smartphones, tablets, video conferencing and other 
communication devices and web applications. Students and teachers began to share different learning resources, assignments, and feedback in the virtual space, which enabled them to maintain a learning community. Alea et al. (2020) found that teachers who had more ICT knowledge performed much better during the first wave of the Covid-19 pandemic than teachers who had less such knowledge. However, Dhawan et al. (2020) reported feelings of anxiety and depression in students and teachers who did not have the necessary skills to use ICT. It is also important that all those involved in distance learning have had the appropriate equipment and access to the Internet, as its absence or poor equipment can significantly slow down the entire learning process (Favale et al., 2020).

It should be mentioned that online teaching is not as strictly organised as classroom lessons are. As a result, it requires more student self-discipline and the ability to self-regulate to complete all school obligations on time (Wolters, 2003). Since the Covid-19 pandemic was the first such situation when schools were closed for several weeks, some teachers did not have enough knowledge and experience to establish appropriate interaction with students. In addition, students using computer-based learning often do not feel involved in the learning environment, as they spend most of their time doing schoolwork independently (Bouhnik \& Marcus, 2005). Another problem of emergency remote schooling can be excessive workload and consequent fatigue (Brom et al., 2020; Niemi \& Kousa, 2020).

Nevertheless, many authors agree that distance learning offers some advantages over traditional classroom learning. Due to increased interactivity (use of electronic presentations, videos, online exercises and quizzes, group work, independent work), students are more motivated, and therefore better engaged in learning. Students autonomously organise their time to complete school assignments (Cojocariu et al., 2013), and distance learning allows them faster access to teacher's feedback and access to a variety of resources (Dhawan, 2020). Students can access learning content online anywhere and anytime; this type of teaching also saves time (Sadeghi, 2019). Most importantly, distance learning during an epidemic enables continuing schooling for all students without interruption (Mukhtar et al., 2020).

\section{Parental perspectives on emergency remote schooling}

The Covid-19 school closures have required most parents to invest more time helping their children, and parental involvement in children's education increased substantially. Grewenig et al. (2020) conducted a study with 1099 German parents of children in primary and secondary schools 
before and during school closure. The authors found greater parental involvement with academically more successful students before schools were closed. Even though most parents increased the time helping their children during school closure, the parents of academically more successful children increased it even more. Unlike traditional classroom learning, emergency remote learning may cause greater disparities between students due to different opportunities for parental support and assistance (Cullinane \& Montacute, 2020).

During the first wave of the new Covid-19 epidemic in spring 2020, a few studies were conducted to examine parents' attitudes and the situation in households. A survey conducted on a sample of 122 parents of elementary school students in the United States (Garbe et al., 2020) found that parents broadly agreed with the school closure policy. During emergency remote schooling, parents were largely positive about the support given by schools and teachers, but they still faced some problems. The largest problem was the coordination of all their responsibilities, followed by encouraging the child to learn or do schoolwork, helping children with special needs, and having tools and resources for work at home (e.g., lack of access to computers or internet quality, lack of parental knowledge to help the child). Parents also noted the concern about the quality of knowledge that students will acquire during remote schooling.

Brom et al. (2020) conducted a study during the first wave of Covid-19 lockdown in the sample of over 9,80o Czech 1st-9th graders' parents. The authors reported that, on average, their children spent two to four hours a day on schoolwork, older students studied longer. At least half of that time, the children needed parental assistance. Parents helped the children by explaining the instructions for the assignments and the new learning contents and checking their school assignments. The difficulties they reported were lack of time to help their child, a lack of knowledge and skills to use technology and a lack of knowledge of the subject matter. In Latvia, an extensive study was conducted in the first wave of Covid-19 lockdown, involving 27,087 parents of school-aged children and adolescents (Jenavs \& Strods, 2020). Parents were mostly involved in their child's schooling by helping their child to understand school assignments $(74 \%$ of parents), to find relevant information (68\%), to discuss learning strategies with the child (64\%), to form the plan for schoolwork (55\%), and to help the child complete school assignments (41\%). Parental involvement also included encouragement (49\%) and discussion with the child about his emotions and well-being (45\%). Another study of parents of 738 Latvian 
primary school students (Daniela et al., 2021) showed that parents missed advice from educators on how to support their children in the learning process the most. Parents also wished that schools would take more interest in how their children are doing and whether everything necessary for distance learning is available.

The European Commission's Joint Research Centre (Vuorikari et al., 2020) published a report on emergency remote schooling in 11 European countries, including Slovenia. The study included students aged 10 to 18 (n $=5466)$ and their parents $(\mathrm{n}=6192)$. In general, the survey revealed large variations among countries in terms of perceived online learning activities and interactions with teachers through digital means. What the countries had in common was that parents of younger students were more involved in their children's schooling or helped them more in finding learning materials than parents of older students. Furthermore, parents in different European countries were worried about the impact of emergency remote schooling on the quality of students' knowledge and the possible negative impact on students' academic achievement. Most parents included in the study agreed that during the first wave of the Covid-19 pandemic, their children acquired new digital competencies and better self-determination, better organisation skills, and greater involvement in school activities. Over $80 \%$ of Slovenian parents wanted the school to enable their children to interact with schoolmates through online activities.

\section{The present study}

The present study was a part of the authors' larger study project investigating the attitudes of Slovenian adolescent students aged 13 to 18 years and their parents toward emergency remote schooling during the first wave of the Covid-19 pandemic. Parents and adolescent students responded to two separate online questionnaires. In addition to analysing data from a total sample of participants, we also tested differences in attitudes and experiences with emergency remote schooling among three groups of parents and adolescent students (7th-9th-grade primary school, 1st-3rd-year secondary school students, and 4th-year secondary school students). The first set of results with adolescent students (Uršič \& Puklek Levpušček, 2020) showed that students in all three groups spent slightly more time on learning under the distance learning condition than in a physical classroom, with $4^{\text {th }}$-year secondary school graduates reporting the highest proportion of additional time spent on school obligations. A 
significantly higher proportion of $4^{\text {th }}$-year secondary school than primary and secondary school students in Years 1-3 reported a lack of personal contact with teachers, inadequate explanations and poor communication with the teacher, and poor internet connection. Students in all three groups reported problems with motivation to learn and that they acquired lower quality knowledge, which was also less consolidated than is common in physical classes. In contrast, students mostly reported that distance learning was a good experience as they became more independent. They also believe that this type of learning will become important in the future.

In this article, we present the results of the second part of the study project, which focused on parents' attitudes and experiences with emergency remote schooling for their adolescent child and aimed to answer the following questions:

- How do parents of adolescent children view emergency distance education compared to traditional classroom education?

- What are the main difficulties encountered during emergency remote schooling reported by parents?

- What are parents' attitudes toward the quality of online teaching and learning, and what do they think about its prospects?

- Are there differences in the attitudes of parents of adolescent children of different ages?

\section{Method}

\section{Participants}

Data were collected from 495 parents with at least one adolescent child who experienced a remote learning environment during the spring 2020 school closures. Of this sample, 313 were parents of students in the last triad of primary (compulsory) school (Grades 7-9) (63.2\%), 147 were parents of secondary school students (Years 1-3) (29.7\%), and 35 were parents of $4^{\text {th }}$-year secondary school (Year 4$)(7.1 \%)$. The sample included mainly mothers (91.1\%). One hundred sixty-five parents (33.3\%) reported having one school-age child, 209 (42.2\%) reported having two school-age children, and $85(17.1 \%)$ reported having three or more school-age children. Eleven parents reported having completed or not completed primary (compulsory) school (2.3\%), 146 parents had a secondary school diploma (31.3\%), 264 parents reported having a vocational college or university degree (56.6\%), and 45 parents had a postgraduate degree (i.e., Master of Science or $\mathrm{PhD}(9.7 \%)$ ). 


\section{Instruments}

We employed an online survey that included sociodemographic information and questions designed to reveal parents' attitudes about emergency remote schooling. The respondents' demographic information was the gender of the parents, the level of education, the number of school-age children in the household, and the year in which the target child attended school (the last triad of primary school or higher). If there was more than one child in the family attending the last triad of primary school or higher, the instruction was that parents completed the questionnaire for the youngest child in the age group.

The second part of the questionnaire began with the semantic differential type of a rating scale. The participant was asked to assess emergency remote schooling compared to traditional classroom schooling on a 7-point rating scale between two polar adjectives or descriptives (e.g., 'Inefficient-Effective,' 'Complicated-Easy', or 'Less consolidated knowledge-More consolidated knowledge'). The next question asked about the amount of time parents spent helping their child with schoolwork during school closure in comparison to the amount of time helping their child with schoolwork before school closure ('Much less time,' 'Less time,' 'Equal time,' 'More time', 'Much more time', 'I do not help my child with schoolwork'). In the third question, parents were asked about 11 difficulties that they might experience during school closure (e.g., poor internet connection, lack of communication with the teacher, insufficient IT knowledge). Finally, they marked one or more difficulties that were on the list.

For the final part of the online survey, we constructed two sets of items describing parents' attitudes toward the quality of online teaching and learning and its prospects. The first set of 17 items assessed parents' attitudes toward the quality of online lessons, the quality of teachers' remote work with students, and the demandingness of online learning. Parents rated the items on a 5-point scale ( 1 - strongly disagree, 5 - strongly agree). A principal component analysis (PCA) with Oblimin rotation was conducted to examine the component structure of this set of items. Visual examination of the scree plot and eigenvalues of $\geq 1$. 0 indicated three components that accounted for $65 \%$ of the total variance of the items. The observed Kaiser-Meyer-Olkin (KMO) Measure of Sampling Adequacy was 0.902, indicating sound underlying components (Tabachnick \& Fidell, 2000). Bartlett's Test of Sphericity was significant $\left(\chi^{2}=3042.078 ; d f=78 ; p=.000\right)$, indicating good factorability of the correlation matrix. Thirteen items with 
factor loadings $>.60$ were retained to enhance the strength of the three components: Online lessons quality, $\alpha=.83$, five items (e.g., Teachers organise online lessons (via Zoom, Skype, etc.) so that they can explain learning content directly), Teacher's remote help to students, $\alpha=.80$, five items (for example: During remote schooling, it seems that teachers support my child more than in a physical school), and Demandingness of online learning, $\alpha=.86$, three items (e.g., It seems that the scope of learning contents is too large). The second set of six items describes parents' views of prospects and positive experiences with online teaching and learning $(\alpha=.88)$, example items are: 'Online education will become important in the future, 'Emergency remote schooling was a positive experience for me because I learned a lot of new things about my child and myself'. Parents rated the items on a 5-point scale ( 1 - strongly disagree, 5 - strongly agree).

An online survey with all questions and scales can be found in the Appendix. Only 13 items are included regarding parents' attitudes toward the quality of online teaching and learning, which were retained after the component structure analysis.

\section{Procedure}

Participants completed the questionnaire in the $1 k a$ online survey, which took about 12 minutes. We granted participants anonymity and the option to end their participation at any time. The snowball method was used to collect data. We posted the online survey in various social networking groups where people are interested in parenting issues and asked them to participate. We also sent the invitation to participate in the study to various primary and secondary schools, who emailed the parents in their school, inviting them to participate in the study. Data collection took place during the last four weeks of spring school closure, from May 4 to June 3, 2020. Data were analysed using the SPSS statistical software.

\section{Results}

\section{Parents' assessment of emergency remote schooling in comparison with traditional classroom schooling}

Parents rated emergency remote schooling during school closure in spring 2020 compared to traditional classroom education on a 7-point semantic differential rating scale ( 1 - completely agree with the adjective 
written on the left, 7 - completely agree with the adjective written on the right). Table 1 presents $M$ s and SDs for the 12 polar adjectives or descriptives (total sample, the three groups of parents). The mean-scale scores are presented with respect to the possible range of these scores, which correspond to the range of the response scale used ( 1 to 7 ).

\section{Table 1}

Ms and SDs of Parental Rates of Polar Adjectives (Emergency Remote Schooling in Comparison to Traditional Schooling in Classrooms)

\begin{tabular}{lcccc}
\hline & Total & Group 1 & Group 2 & Group 3 \\
\hline Polar adjective (descriptive) & $M(S D)$ & $M(S D)$ & $M(S D)$ & $M(S D)$ \\
Uninteresting vs Interesting & $4.00(1.69)$ & $3.95(1.68)$ & $4.09(1.70)$ & $3.97(1.77)$ \\
Unpleasant vs Pleasant & $3.85(1.68)$ & $3.81(1.68)$ & $4.07^{\mathrm{a}}(1.63)$ & $3.31^{\mathrm{b}}(1.76)$ \\
Complicated vs Easy & $3.44(1.63)$ & $3.38(1.60)$ & $3.67(1.65)$ & $3.14(1.75)$ \\
Difficult vs Effortless & $3.44(1.95)$ & $3.33(1.94)$ & $3.73(1.90)$ & $3.11(2.17)$ \\
Inefficient vs Effective & $3.99(1.79)$ & $3.84^{\mathrm{b}}(1.75)$ & $4.31^{\mathrm{a}}(1.89)$ & $3.94(1.59)$ \\
Non-Diverse vs Diverse & $3.78(1.72)$ & $3.76(1.73)$ & $3.87(1.73)$ & $3.51(1.65)$ \\
Non-Consolidated vs Consolidated & $2.90(1.64)$ & $2.91(1.72)$ & $2.97(1.53)$ & $2.57(1.34)$ \\
Knowledge & $3.14(1.73)$ & $3.14(1.81)$ & $3.13(1.60)$ & $3.20(1.59)$ \\
Less vs More Knowledge & $3.74(1.94)$ & $3.73^{\mathrm{b}}(1.91)$ & $3.97^{\mathrm{b}}(1.96)$ & $2.91^{\mathrm{a}}(1.87)$ \\
Stressful vs Relaxed & $3.59(1.82)$ & $3.53(1.83)$ & $3.71(1.80)$ & $3.63(1.88)$ \\
Less vs More Motivation & $4.02(1.91)$ & $3.93(1.89)$ & $4.23(1.91)$ & $3.89(2.06)$ \\
\hline Causing More vs Less Difficulties & & & & \\
\hline
\end{tabular}

Note. Group 1 = parents of students from the last triad of primary (compulsory) school (Grades 7-9), Group 2 = parents of high school students (Years 1-3), Group $3=$ parents of $4^{\text {th }}$-year secondary school (Year 4). ${ }^{a b}$ denotes statistically significant difference between the groups.

The results are shown as the average score per each pair of adjectives (descriptives). Lower scores mean lower parental rates of emergency remote schooling.

As shown in Table 1, parents assessed emergency remote schooling as more complicated and difficult than traditional schooling in classrooms. They also reported more difficulties motivating their children and agreed that such schooling provides less knowledge to the students, which is also less consolidated than in the physical classroom setting. The average scores of other polar adjectives were around the midpoint of the scale (neutral). A one-way ANOVA was performed to determine whether parents of different aged adolescent children differed in their attitudes towards emergency remote schooling. The results showed that the three groups of parents differed significantly in polar adjectives Unpleasant vs Pleasant $(F(2,492)$ $\left.=3.24, p<.04, \eta^{2}=.013\right)$, Inefficient vs Effective $(F(2,492)=3.42, p<.03$, 
$\left.\eta^{2}=.014\right)$, and Stressful vs Relaxed $\left(F(2,492)=4.30, p<.01, \eta^{2}=.017\right)$. Post-hoc comparisons (Fisher's Least Significant Difference) showed that parents of $4^{\text {th }}$-year secondary school students assessed emergency remote schooling as more unpleasant and stressful than parents of secondary school students in Years 1-3 ( $p<.01$ and $p<.001$, respectively). They also assessed emergency remote schooling as more stressful than parents of students from the last triad of primary school $(p<.001)$. Parents of students from the last triad of primary school assessed emergency remote schooling as more inefficient $(p<.05)$ than parents of secondary school students (Years 1-3).

Figure 1 shows the percentages of parents according to the amount of time spent helping their child with schoolwork during school closure compared to the amount of time helping their child with schoolwork before school closure. Kruskal-Wallis $\mathrm{H}$ test showed that the level of parental help with schoolwork decreases with the age of the adolescent child $\left(\chi^{2}(2)=\right.$ $\left.96.3, p<.001, \eta^{2}=.213\right)$. Parents of primary school adolescent children were more involved in their child's schooling during the Covid-19 school closure than before it than parents of secondary school students in Years 1-3 ( $W$ $=-12.19, p<.001)$ and secondary school students in Year $4(W=-8.49, p<$ .001). About one-fifth of the parents in the first group reported that they do not help their adolescent child with schoolwork; $55 \%$ of the parents in this group spent more time and much more time helping their adolescent child during school closure than before it. About $65 \%$ of parents of secondary school students (Years 1-3) reported that they do not help their adolescent child with schoolwork and $18.4 \%$ of parents in this group spent more time and much more time helping their adolescent child during school closure than before it. Most parents of $4^{\text {th }}$-year secondary school students were not involved in their adolescent child's remote schooling; however, 14.3\% of parents in this group reported more time and much more time helping their adolescent child during school closure. 


\section{Figure 1}

Parental Assessment of Time Spent Helping Their Adolescent Child with Schoolwork During vs Before School Closure

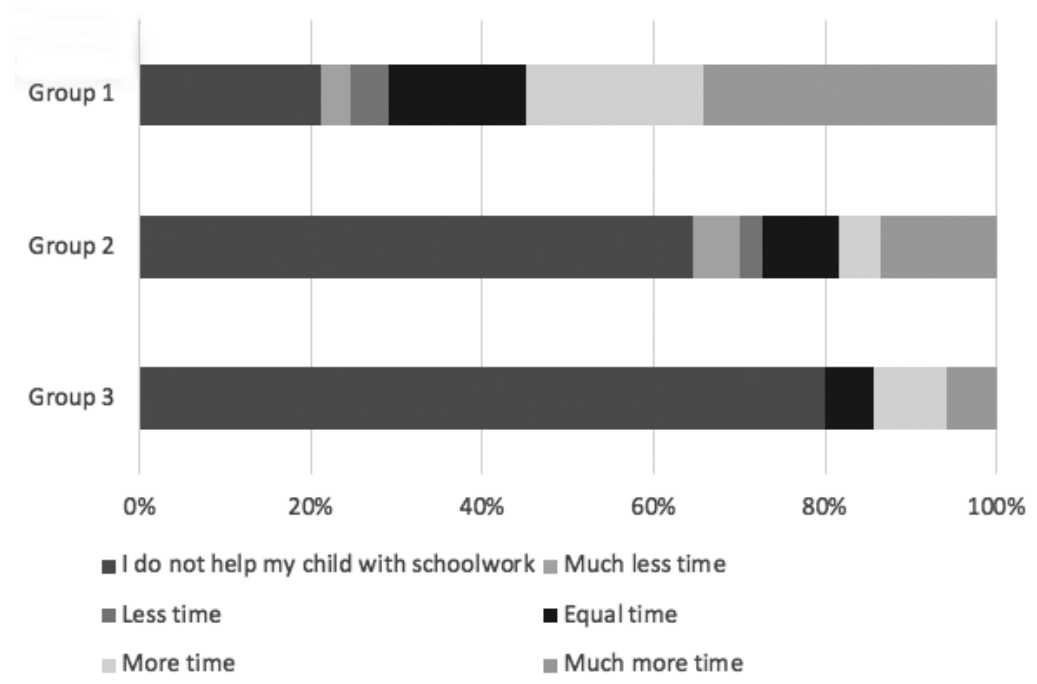

Note. Group 1 = parents of students from the last triad of primary (compulsory) school (Grades 7-9), Group 2 = parents of secondary school students (Years 1-3), Group 3 = parents of secondary school students (Year 4).

\section{Parents' report of difficulties experienced during emergency remote schooling}

Next, parents choose among 11 difficulties that their families might experience during school closure. Parents perceived the most difficulties in the following domains: coordination between work and child's school (40.81\%), more school-aged children in the household (34.55\%), a lack of personal contact with the teacher (29.09\%), a lack of child's motivation for schoolwork (23.43\%), and a lack of knowledge to help the child learn $(22.63 \%)$. Figures $2 \mathrm{a}$ and $2 \mathrm{~b}$ present the percentage of parents in the three groups who marked a particular item as a difficulty during school closure. As can be seen in Figures $2 a$ and $2 b$, the difficulties that were most often marked by parents of primary school children were 'Coordination between work and school' (53.04\%), 'More school-aged children in the household' (41.21\%), and 'I miss personal contact with the teacher' (32.59\%). In contrast, parents of secondary school students (Years 1-3) most often marked difficulties, such as 'More school-aged children in the 
household' (25.17\%), 'I do not have enough knowledge to help my child learn' (23.13\%), and 'Poor internet connection' (20.41\%), while parents of $4^{\text {th }}$-year secondary school graduates most often marked difficulties, such as 'I miss personal contact with the teacher' (40.00\%), 'Poor communication with the teacher' (28.57\%), and 'Difficulties in finding suitable learning material' $(25.71 \%)$.

\section{Figure 2a}

Percentages of Parents Who Marked Each Difficulty Experienced During Emergency Remote Schooling

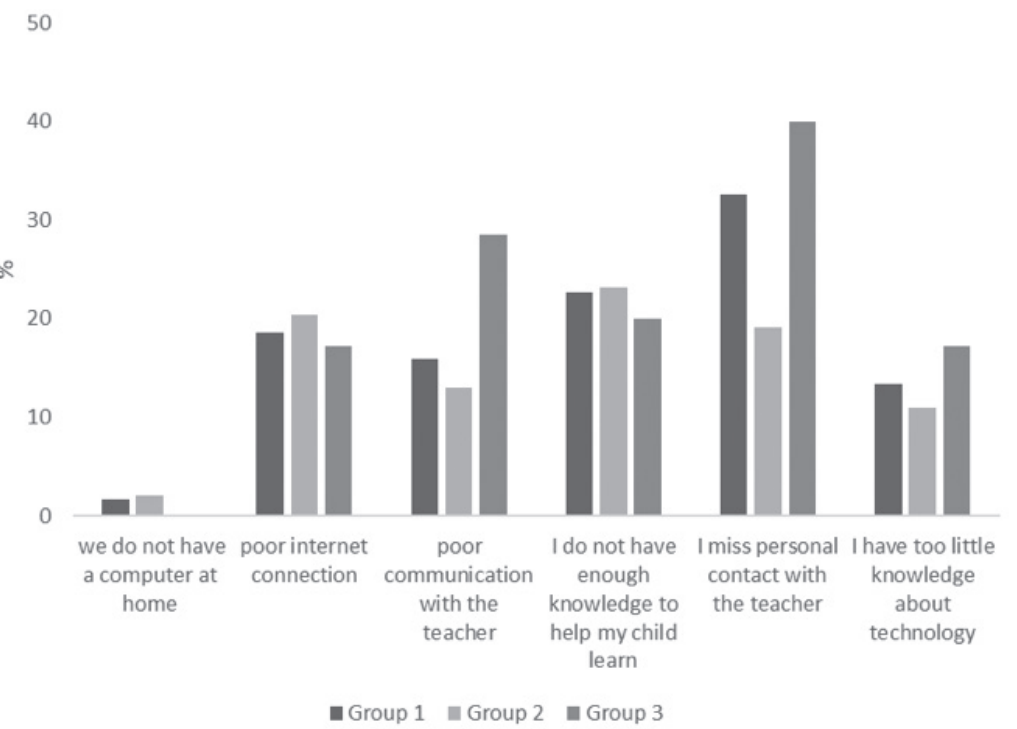

Note. Group 1 = parents of students from the last triad of primary (compulsory) school (Grades 7-9), Group 2 = parents of secondary school students (Years 1-3), Group 3 = parents of secondary school students (Year 4). 


\section{Figure 2b}

Percentages of Parents Who Marked Each Difficulty Experienced During Emergency Remote Schooling

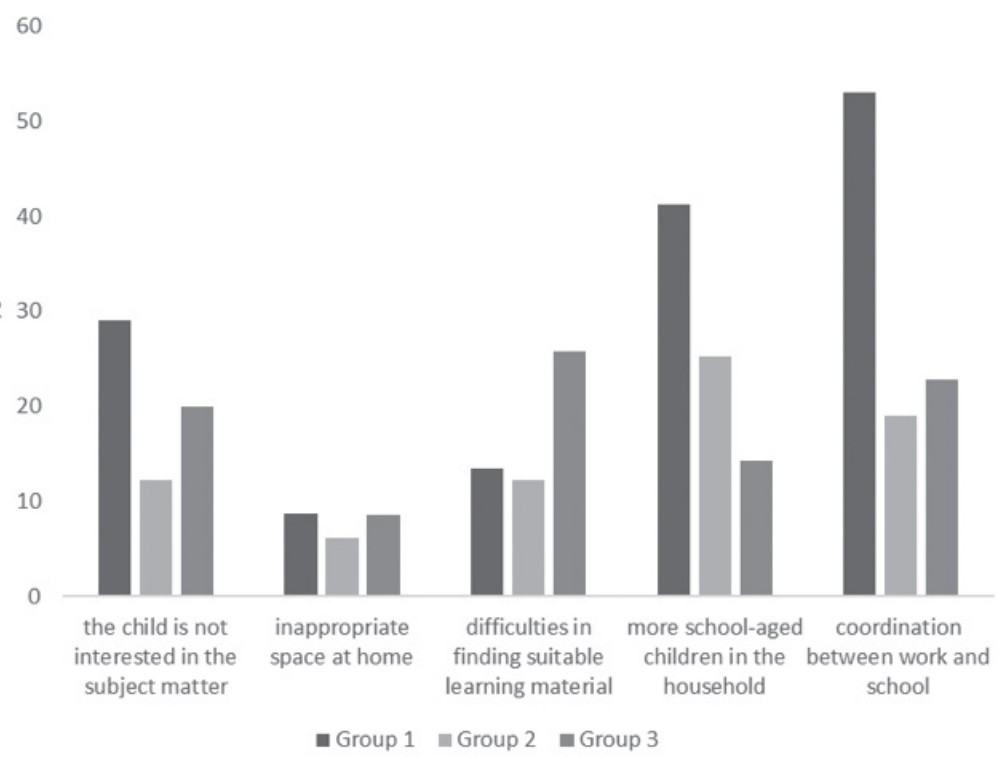

Note. Group 1 = parents of students from the last triad of primary (compulsory) school (Grades 7-9), Group 2 = parents of secondary school students (Years 1-3), Group 3 = parents of secondary school students (Year 4).

Comparisons between the three groups of parents showed that parents of primary school adolescent children marked 'coordination between work and school' $\left(\chi^{2}(2)=52.9, p<.001\right)$ and 'more school-aged children in the household' $\left(\chi^{2}(2)=18.2, p<.001\right)$ more often as difficulties during emergency remote schooling than the two groups of parents of secondary school students. The three groups of parents also differed in their report on 'I miss personal contact with the teacher' $\left(\chi^{2}(2)=11.1, p<.004\right)$, with parents of primary school adolescent children and parents of $4^{\text {th }}$-year secondary school students marking this difficulty more often than parents of secondary school students in Years 1-3. In addition, the three groups of parents differed significantly in their report on 'The child is not interested in the subject matter' $\left(\chi^{2}(2)=16.0, p<.001\right)$. Parents of primary school adolescent children marked this difficulty more often than the other two groups of parents. 


\section{Parents' attitudes about the quality of online teaching and learning and its prospects}

\section{Table 2}

Ms and SDs for the Online Teaching and Learning Scales

\begin{tabular}{lcccc}
\hline & Total & Group 1 & Group 2 & Group 3 \\
\hline Scale & $M(S D)$ & $M(S D)$ & $M(S D)$ & $M(S D)$ \\
Online lessons quality & $2.96(.96)$ & $2.85^{\mathrm{a}}(.97)$ & $3.20^{\mathrm{b}}(.90)$ & $2.93(.94)$ \\
Teacher's remote help to students & $3.58(.79)$ & $3.63^{\mathrm{a}}(.78)$ & $3.54(.75)$ & $3.28^{\mathrm{b}}(.89)$ \\
Demandingness of online learning & $3.02(1.12)$ & $3.13^{\mathrm{b}}(1.0)$ & $2.71^{\mathrm{a}}(1.12)$ & $3.37^{\mathrm{b}}(1.13)$ \\
\hline
\end{tabular}

Note. Group 1 = parents of students from the last triad of primary (compulsory) school (Grades 7-9), Group 2 = parents of secondary school students (Years 1-3), Group 3 = parents of secondary school students (Year 4). ${ }^{\mathrm{ab}}$ denotes statistically significant difference between the groups.

The scale results are shown as the average score per item. The range of the response scale was 1 to 5 .

As shown in Table 2, the total score on the Online lessons quality scale is close to the value of 3 and indicates an intermediate level of parental rate of online teaching. It seems that parents were quite undecided, or the result might indicate large differences among Slovenian schools and teachers in the quality of online teaching. The above-average total score on the Teacher's remote help to students scale indicates that parents perceived teachers' work with students quite positively; they mostly agreed that the instructions for schoolwork were sufficiently clear and that teachers give students enough feedback, communicate with them accordingly and offer them enough support. The total score on the Demandingness of online learning was around the midpoint of the scale. The results showed that the three groups of parents differed significantly at all three scales, Online lessons quality $\left(F(2,492)=7.11, p<.001, \eta^{2}=.028\right)$, Teacher's remote help to students $\left(F(2,492)=3.34, p<.036, \eta^{2}=.013\right)$, and Demandingness of online learning $\left(F(2,492)=9.12, p<.001, \eta^{2}=.036\right)$. Post-hoc comparisons (Fisher's Least Significant Difference) showed that the parents of students from the last triad of primary school assessed online lessons quality lower than the parents of secondary school students (Years 1-3) $(p=.000)$. Furthermore, the parents of primary school students assessed the teacher's support and help to students with schoolwork more positively than parents of $4^{\text {th }}$ year secondary school students did $(p=.03)$. At last, parents of secondary school students (Years 1-3) rated the demandingness of online learning lower than the parents of primary school students and the parents of $4^{\text {th }}$ year secondary school students ( $p=.000$ and $p=.001$, respectively). 
In the last part of the questionnaire, parents assessed prospects and positive experiences with online teaching and learning. Table 3 shows the average scores on single items.

\section{Table 3}

Parental Assessment of Prospects and Positive Experiences with Online Teaching and Learning

\begin{tabular}{lcc}
\hline Item & M & SD \\
\hline Online learning could replace physical classroom learning in the future. & 2.23 & 1.30 \\
Remote schooling has enabled my child to perform deep learning. & 2.44 & 1.26 \\
Remote schooling has made my child more independent. & 2.86 & 1.29 \\
$\begin{array}{l}\text { When the epidemic is over, classes should continue to be held occasionally (e.g., } \\
\text { once a week) in this way. }\end{array}$ & 2.67 & 1.49 \\
$\begin{array}{l}\text { Remote schooling has been a positive experience for me because l learned a lot } \\
\text { of new things about the child and myself. }\end{array}$ & 3.10 & 1.39 \\
Online education will become important in the future. & 3.34 & 1.32 \\
\hline
\end{tabular}

Note. The results are shown as the average score per item. The range of the response scale was 1 to 5 .

The results showed that $51.1 \%$ of parents agreed or strongly agreed about the importance of online education in the future. Despite their agreement with the importance of such education in the future, most parents $(64.2 \%)$ disagree or strongly disagree with the statement that online learning will replace physical classroom learning. Similarly, $47 \%$ of parents do not support the occasional use of online learning when the epidemic is over. On average, parents were quite neutral about the statement that remote schooling was a positive experience for them and that they learned a lot about themselves and the child during this period. $34.4 \%$ of parents disagree or strongly disagree with this statement. A total of $35.3 \%$ of parents agreed or strongly agreed that remote schooling has made their children more independent.

\section{Discussion}

The emergence of the new Covid-19 pandemic and the associated remote schooling have greatly affected school children, their parents and teachers around the globe. The transition to the new way of teaching and learning required much adjustment from everyone involved. To date, there have been a few studies that examined parents' views on Covid-19 school closures (e.g., Brom et al., 2020; Daniela et al., 2021; Garbe et al., 
2020; Grewenig et al., 2020; Jenavs \& Strods, 2020; Ribeiro et al., 2021). Parents are an important source of support and help in children's education in non-pandemic times, while their educational role becomes even more important in emergent situations, such as the epidemic, when school children's daily routines change and need to be adapted to the new 'online reality'. On the other hand, adolescents seem to represent a vulnerable group during state lockdowns. When countries are almost completely on lockdown and social contact is restricted, adolescents are at a severe disadvantage in gaining important social experiences and have fewer opportunities to seek social support and communication with people outside their families (Brooks et al., 2020). In addition, they have to deal with new ways of learning complex content, and final-year secondary school students in some countries are pressured by the upcoming state exam for which they have to prepare remotely. Therefore, our project aimed to investigate the attitudes and experiences of Slovenian parents and adolescent children with emergency remote schooling during the first wave of the Covid-19 pandemic. In this article, we present the results on the parental perspective, while the adolescent children perspective has been presented elsewhere (Uršič \& Puklek Levpušček, 2020).

The results showed that parents assessed emergency remote schooling as more complicated and difficult than traditional classroom schooling. They also estimated that their children gained less knowledge, which was also less consolidated. Parents' reports are very similar to the parallel reports of adolescent students (Uršič \& Puklek Levpušček, 2020); 50-60\% of adolescent students assessed emergency remote schooling as more complicated and difficult than traditional schooling and $60-70 \%$ of them considered that they gained less knowledge, which was also less consolidated. Parents' reports of difficulty in motivating a child probably reflect the actual poorer motivation of children; $55 \%$ of adolescent students assessed remote schooling as less motivating than traditional classroom education (Uršič \& Puklek Levpušček, 2020).

The second research question related to the main difficulties experienced by parents during emergency remote schooling. Parents of schoolage children reported that they experienced the most difficulties coordinating between work and school and having more school-age children in the household. Both of these difficulties were reported primarily by parents of children in the last triad of primary school. Parents also reported a lack of personal contact with the teacher, which was reported more often by parents of final-year secondary school students. In addition, about 
one-fifth of parents reported a lack of child motivation and knowledge to help their child with schoolwork. In the US sample, Garbe et al. (2020) reported parents' main difficulties coordinating between different responsibilities and motivating students for schoolwork. Brom et al. (2020) found that parents in the Czech Republic mainly mentioned a lack of time for all responsibilities, insufficient knowledge about ICT, and a lack of knowledge to help the child with schoolwork.

Similarly, Portuguese parents (Ribeiro et al., 2021) reported investing much time to help their children, especially parents of primary school children. All this led to difficulties in coordinating work and school activities. We can conclude that Slovenian parents faced similar problems during emergency remote schooling as elsewhere in the world - mainly the lack of time to handle the child's remote schooling and the lack of knowledge to help their child with school responsibilities.

The third research question focused on parents' attitudes toward online teaching and learning and its prospects. Parents in our sample were generally satisfied with the teachers' work, as teachers tried to create a positive online experience for students, provide knowledge of the highest quality, and offer support and help with school activities. As also found in previous studies (e.g., Garbe et al., 2020), parents perceived school and teacher support during school closures quite positively. However, parental perception of the quality of online instruction was around the midpoint of the scale. This result might reflect differences in distance learning approaches among Slovenian schools, as well as teachers' competencies and willingness to use different teaching methods that made online learning more effective. According to the teachers' reports (Rupnik Vec et al., 2020), most Slovenian teachers adapted to the situation very quickly and immediately started teaching through different online platforms. Nevertheless, in the first wave of school closures, about a third of teachers in primary schools and a quarter of teachers in secondary schools sent students only instructions and materials for individual work. As a reminder, the findings of the European Commission's Joint Research Centre in 11 European countries showed that only $40 \%$ of Slovenian students in the first wave of school closures had frequent daily online learning activities and/or daily contact with teachers (Vuorikari et al., 2020). Similar to reports on adolescent students (Uršič \& Puklek Levpušček, 2020), parents agreed that online education would become important in the future. However, the results showed a less positive evaluation of remote schooling by parents than was the case in the sample of adolescent students. 
The last research question addressed possible differences in the attitudes of parents of adolescent children of different ages. The results showed that parents of primary school children were significantly more involved in their child's schooling during the epidemic than parents of the other two age groups. As shown in other surveys (e.g., Ribeiro et al., 2021; Vuorikari et al., 2020), the frequency of parents' involvement in their child's emergency remote schooling decreased with the child's age. Consistent with previous findings (e.g., Grewenig et al., 2020), parents who reported being involved in their child's schooling reported higher or much higher involvement rates than pre-epidemic levels. As parents of primary school children were more involved in their child's schooling, they were more aware of their children's school activities and responsibilities. Accordingly, they were more critical of emergency remote schooling than parents of secondary school students (Years 1-3) and assessed this type of schooling as less effective. In contrast, parents of final-year secondary school students were even more critical of emergency remote schooling than parents of primary school students, even though most of them were not directly involved in their child's schooling. The reason for this was in the fact that the former group of students were preparing for the Matura, which is decisive for university enrolment.

In the first wave of the new Covid-19 pandemic, we studied emergency remote schooling, when students, their parents, and teachers were getting used to the 'new reality'. The present study results cannot be generalised to the emergency remote schooling situation in the second wave of the Covid-19 pandemic in the fall and winter of 2020/21, when all stakeholders already had some experience with distance education and learning at home. Another limitation of the present study could be the biased sample of parents. The survey was conducted online because in-person interviews were not feasible. We searched for participants in Facebook interest groups and asked various schools to distribute the online survey among parents of school children via email. In this way, only parents who were likely to be interested in parenting and who had a digital device and Internet access were included in the sample. It should also be noted that our sample did not uniformly include parents with different levels of education. Twothirds of the parents in the sample had post-secondary education levels. A recent meta-analysis on the moderating effects of socioeconomic status in the parental involvement-academic achievement relation (Tan et al., 2019) showed that children of parents with higher levels of education benefit more from parental involvement in school than children of parents with lower levels of education do. 
Further studies are needed to investigate the situation of extended emergency remote schooling in the second wave of the Covid-19 pandemic. In addition, research should follow the experiences of school children and their parents in both waves of the Covid-19 pandemic, as this would provide a broader picture of the changes in educational approaches that may occur between school closures and the changes in parents' and students' attitudes toward remote schooling.

\section{Conclusions}

The results of the study shed light on how Slovenian parents of adolescent children perceived emergency remote schooling during the first wave of the Covid-19 pandemic. Overall, parents rated emergency remote schooling as more complicated and less motivating compared to traditional teaching and learning. They reported that students acquired less knowledge, which was also less consolidated. Students and their parents faced some difficulties during emergency remote schooling; however, parents were generally satisfied with teachers' support to students. They also held an optimistic view of the importance of online education in the future.

Our results imply that special attention should be paid to the two vulnerable groups of students, namely early adolescents in the last triad of primary school and final-year secondary school students. In the last grades of primary school, adolescent students have to cope with larger amounts of learning material, which is also more complex than in the preceding school years. Abstract thinking in early adolescence is not yet fully developed. Also, many students at this age do not have fully developed self-regulation skills that are crucial for successful learning. Another vulnerable group of students during the first wave of the pandemic were secondary school students who took the Matura exam in the same form as in previous years, although preparations for the exam were shortened due to the epidemic. Similar to the reports of the $4^{\text {th }}$-year secondary school students (Uršič \& Puklek Levpušček, 2020), the parents of this age group reported a lack of personal contact with the teacher and poor communication with the teacher as the most frequent difficulties. In addition, they rated remote schooling as the most challenging among the three groups of parents. Important goals of policymakers in implementing Slovenian Matura 2020 were to ensure the stability of the Matura system, to enable the completion of secondary school education and make a smooth transition to tertiary education, and to ensure intergenerational comparability. Although 
all these arguments sound reasonable, more attention should be paid to possible modifications of the Matura exam in the following years, which should take into account prolonged distance education in the second wave of the pandemic and psychosocial difficulties of secondary school students during socially isolated distance education.

\section{References}

Alea, L., Fabrea, M., Roldan, R., \& Farooqi, A. (2020). Teachers' COVID-19 awareness, distance learning education experiences and perceptions towards institutional readiness and challenges. International Journal of Learning, Teaching and Educational Research, 19(6), 127-144. https://doi. org/10.26803/ijlter.19.6.8

Auger K. A., Shah S. S., Richardson T., Hartley, D., Hall, M., Warniment, A., Timmons, K., Bosse, D., Ferris, S. A., Brady, P. W., Schondelmeyer, A. C., \& Thomson, J. E. (2020). Association between statewide school closure and COVID-19 incidence and mortality in the US. JAMA, 324(9), 859-870. 10.1001/jama.2020.14348

Bouhnik, D., \& Marcus, T. (2005). Interaction in distance-learning courses. JASIST, 57, 299-305. https://www.researchgate.net/publication/220435681_Interaction_in_distance-learning_courses Bregar, L., Zagmajster, M., \& Radovan, M. (2020). E-izobraževanje za digitalno družbo [E-learning for digital societies]. Andragoški center Slovenije. https://www.acs.si/digitalna-bralnica/e-izobrazevanjeza-digitalno-druzbo/

Brom, C., Lukavský, J., Greger, D., Hannemann, T., Straková, J., \& Švaríček, R. (2020). Mandatory home education during the COVID-19 lockdown in the Czech Republic: A rapid survey of 1st-9th graders' parents. Frontiers in Education, 5, 1-8. https://doi.org/10.3389/feduc.2020.00103 Brooks, S. K., Webster, R. K., Smith, L. E., Woodland, L., Wessely, S., Greenberg, N., \& Rubin, G. J. (2020). The psychological impact of quarantine and how to reduce it: Rapid review of the evidence. The Lancet, 20, 395-912. https://doi.org/10.1016/So140-6736(20)30460-8

Cojocariu, V. M., Lazar, I., Nedeff, V., \& Lazar, G. (2013). SWOT analysis of E-learning educational services from the perspective of their beneficiaries. Procedia-Social and Behavioral Sciences, 116, 1999-2003. https://doi.org/10.1016/S2468-2667(20)30090-6.

Cowling, B. J., Ali, S. T., Ng, T. W., Tsang, T. K., Li, J. C., Fong, M. W., Liao, Q., Kwan, M. YW., Lee, S. L., Chiu, S. S., Wu, J. T., Wu, P., \& Leung, G. M. (2020). Impact assessment of non-pharmaceutical interventions against COVID-19 and influenza in Hong Kong: An observational study. MedRxiv, 5(5), 279-288. https://doi.org/10.1101/2020.03.12.2003466o Cullinane, C., \& Montacute, R. (2020). COVID-19 and social mobility impact brief \#1: School shutdown. The Sutton Trusts. https://dera.ioe.ac.uk//35356/1/COVID-19-Impact-Brief-SchoolShutdown.pdf

Daniela, L., Rubene, Z., \& Rudolfa, A. (2021). Parents' perspectives on remote learning in the pandemic context. Sustainability, 13, 3640. https://doi.org/10.339o/su13073640 
Dhawan, S. (2020). Online learning: A panacea in the time of COVID-19 crisis. Journal of Educational Technology Systems, 49(1), 5-22. https://doi.org/10.1177/0047239520934018

Favale, T., Soro, F., Trevisan, M., Drago, I., \& Mellia, M. (2020). Campus traffic and e-learning during COVID-19 pandemic. Computer Networks, 176. https://reader.elsevier.com/reader/sd/pii/S1389128620 306046? token=9BF56008E6DoB10D99D34E71AB499A79BB9ED2D6316265061815EEE6CF40A5A95 A64DF41369BCD84D78F1597341C8C18

Ferri, F., Grifoni, P., \& Guzzo, T. (2020). Online learning and emergency remote teaching: Opportunities and challenges in emergency situations. Societies, 10(4), 86. https://www.mdpi. com/2075-4698/10/4/86

Garbe, A., Ogurlu, U., Logan, N., \& Cook, P. (2020). COVID-19 and remote learning: Experiences of parents with children during the pandemic. American Journal of Qualitative Research, 4(3), 45-65. https://www.ajqr.org/download/parents-experiences-with-remote-education-during-covid-19-schoolclosures-8471.pdf Gov.si (2020). Koronavirus (SARS-CoV-2). Vladni portal Republike Slovenije. https://www.gov.si/ teme/koronavirus-sars-cov-2/

Grewenig, E., Lergetporer, P., Werner, K., Woessmann, L., \& Zierow, L. (2020). COVID-19 and educational inequality: How school closures affect low-and high-achieving students. CESifo Working Paper 8648. https://www.cesifo.org/DocDL/cesifo1_wp8648.pdf

Hens, N., Ayele, G., Goeyvaerts, N., Aerts, M., Mossong, J., Edmunds, J., \& Beutels, P. (2009). Estimating the impact of school closure on social mixing behavior and the transmission of close contact infections in eight European countries. BMC infectious disease, 9(187). https://doi.org/10.1186/1471-2334-9-187 Hodges, C., Moore, S., Lockee, B., Trust, T., \& Bond, A. (2020). The difference between emergency remote teaching and online learning. Educause Review. https://er.educause.edu/articles/2020/3/thedifference-between-emergency-remote-teaching-and-online-learning Jackson, C., Vynnycky, E., \& Mangtani, P. (2016). The relationship between school holidays and transmission of influenza in England and Wales. American Journal of Epidemiology, 184(9), 644-651. https://academic.oup.com/aje/article/184/9/644/2332838 Jenavs, E., \& Strods, J. (2020). Managing a school system through shutdown: Lessons for school leaders. Edurio \& Ministry of Education and Science of the Republic of Latvia. http://www.oecd.org/ education/Latvia-managing-school-system-through-shutdown-lessons-for-school-leaders.pdf Mukhtar, K., Javed, K., Arooj, M., \& Sethi, A. (2020). Advantages, limitations and recommendations for online learning during COVID-19 pandemic era. Pakistan Journal of Medical Sciences, 36. https:// doi.org/10.12669/pjms.36.COVID19-S4.2785

Niemi, H. M., \& Kousa, P. (2020). A case study of students' and teachers' perceptions in a Finnish high school during the COVID pandemic. International Journal of Technology in Education and Science (IJTES), 4(4), 352-369. https://doi.org/10.46328/ijtes.v4i4.167

Ribeiro, L. M., Cunha, R. S., Silva, M. C. A., Carvalho, M., \& Vital, M. L. (2021). Parental involvement during pandemic times: Challenges and opportunities. Education Sciences, 11, 302. https://doi. org/10.3390/educsci11060302 
Rupnik Vec, T., Preskar, S., Slivar, B., Zupanc Grom, R., Kregar, S., Holcar Brunauer, A., Bevc, V., Mithans, M, Grmek, M., \& Musek Lešnik, K. (2020). Analiza izobraževanja na daljavo v času epidemije Covid-19 v Sloveniji [The analysis of distance education in Slovenia during Covid-19 epidemic]. Zavod Republike Slovenije za šolstvo. https://www.dlib.si/stream/URN:NBN:SI:DOC$\mathrm{X}_{3}$ BSQ9IN/d1f7defb-eofa-4ad5-a9c5-975068de1020/PDF Sadeghi, M. (2019). A shift from classroom to distance learning: Advantages and limitations. International Journal of Research in English Education, 4(1), 80-88. http://ijreeonline.com/article-1132-en.pdf

Tabachnick, B. G., \& Fidell L. S. (2000). Computer-assisted research design and analysis. Allyn \& Bacon, Inc.

Tan, C. Y., Lyu, M., \& Peng, B. (2019). Academic benefits from parental involvement are stratified by parental socioeconomic status: A meta-analysis. Parenting: Science and Practice. Advance online publication. https://doi.org/10.1080/15295192.2019.1694836

Telli Yamamoto, G., \& Altın, D. (2020). The coronavirus and rising of online education. Journal of University Research, 3(1), 25-34.

UNESCO. (2020). Education: From disruption to recovery. Unesco. https://en.unesco.org/covid19/ educationresponse

UNICEF. (2021). Covid-19 and school closures: One year of education disruption. Unicef. https://data. unicef.org/resources/one-year-of-covid-19-and-school-closures/

Uršič, L., \& Puklek Levpušček, M. (2020). Učenci zadnje triade OŠ in dijaki o učenju na daljavo med epidemijo COVID-19 [Adolescent students about emergency remote schooling during Covid-19 pandemic]. In Ž. Lep \& K. Hacin Beyazoglu (Eds.), Psihologija pandemije: posamezniki in družba v času koronske krize (pp. 191-203). Znanstvena založba Filozofske fakultete Univerze v Ljubljani. Vuorikari, R., Velicu, A., Chaudron, S., Cachia, R., \& Di Gioia, R. (2020). How families handled emergency remote schooling during the Covid-19 lockdown in spring 2020 -Summary of key findings from families with children in 11 European countries. Publications Office of the European Union. https://publications.jrc.ec.europa.eu/repository/bitstream/JRC122303/remote_schooling_families_ summary.pdf

Viner, R. M., Russell, S. J., Croker, H., Packer, J., Ward, J., Stansfield, C., Mytton, O., Bonell, C., \& Booy, R. (2020). School closure and management practices during coronavirus outbreaks including COVID-19: A rapid systematic review. The Lancet. Child \& Adolescent Health, 4, 397-404. https://doi. org/10.1016/S2352-4642(20)30095-X

WHO. (2020). Coronavirus disease 2019 (COVID-19) Situation report - 1. https://www.who.int/docs/ default-source/coronaviruse/situation-reports/20200121-sitrep-1-2019-ncov.pdf?sfvrsn=20a99c10_4 Wolters, C. (2003). Regulation of motivation: Evaluating an underemphasized aspect of self-regulated learning. Educational Psychologist, 38, 189-205. https://doi.org/10.1207/S15326985EP3804_1 Zhang, W., Wang, Y., Yang, L., \& Wang, C. (2020). Suspending classes without stopping learning: China's education emergency management policy in the COVID-19 outbreak. Journal of Risk and Financial Management, 13(3), 1-6. https://doi.org/10.3390/jrfm13030055 


\section{Appendix}

Online survey on parents' attitudes about emergency remote schooling

Gender:

- Male

- Female

The year of a target adolescent child's schooling:

- $\quad 7^{\text {th }}$ (primary school)

- $\quad 8^{\text {th }}$ (primary school)

- $\quad 9^{\text {th }}$ (primary school)

- $\quad 1^{\text {st }}($ secondary school)

- $\quad 2^{\text {nd }}($ secondary school)

- $\quad 3^{\text {rd }}$ (secondary school)

- $\quad 4^{\text {th }}$ (secondary school)

The number of school-aged children in the household:

Education level:

- Unfinished primary (compulsory) school

- $\quad$ Finished primary (compulsory) school

- Secondary school degree

- Vocational college

- University degree

- $\quad$ Postgraduate degree (Master of Science or a PhD degree)

There are statements that are designed to decide between two adjectives, one being positive and the other negative. Please mark your agreement with the written statements on a scale from 1 to 7 , where 1 means you completely agree with the adjective on the left and 7 that you completely agree with the adjective on the right. 
Evaluate how you feel about emergency remote schooling during the Covid-19 pandemic compared to traditional schooling.

$\begin{array}{lllllllll}\text { Uninteresting } & 1 & 2 & 3 & 4 & 5 & 6 & 7 & \text { Interesting } \\ \text { Unpleasant } & 1 & 2 & 3 & 4 & 5 & 6 & 7 & \text { Pleasant } \\ \text { Complicated } & 1 & 2 & 3 & 4 & 5 & 6 & 7 & \text { Easy } \\ \text { Difficult } & 1 & 2 & 3 & 4 & 5 & 6 & 7 & \text { Effortless } \\ \text { Inefficient } & 1 & 2 & 3 & 4 & 5 & 6 & 7 & \text { Effective } \\ \text { Non-Diverse } & 1 & 2 & 3 & 4 & 5 & 6 & 7 & \text { Diverse } \\ \text { Non-Consolidated } & 1 & 2 & 3 & 4 & 5 & 6 & 7 & \text { Consolidated Knowledge } \\ \text { Less } & 1 & 2 & 3 & 4 & 5 & 6 & 7 & \text { More Knowledge } \\ \text { Stressful } & 1 & 2 & 3 & 4 & 5 & 6 & 7 & \text { Relaxed } \\ \text { Less } & 1 & 2 & 3 & 4 & 5 & 6 & 7 & \text { More Motivation } \\ \text { Causing More } & 1 & 2 & 3 & 4 & 5 & 6 & 7 & \text { Less Difficulties }\end{array}$

In comparison to schooling prior to school closures, I daily spend helping my child with schoolwork:

- Much less time

- Less time

- Equal time

- More time

- Much more time

- I do not help my child with schoolwork

Mark the problems that you face during the emergency remote schooling.

- We do not have a computer at home

- Poor internet connection

- Poor communication with the teacher

- I do not have enough knowledge to help my child learn

- I miss personal contact with the teacher

- I have too little knowledge about technology

- The child is not interested in the subject matter

- Inappropriate space at home

- $\quad$ Difficulties in finding suitable learning material

- More school-aged children in the household

- Coordination between work and school 
Read the following statements and rate your agreement with them on a scale from 1 to 5 , where 1 means you strongly disagree with the statement and 5 means you strongly agree with the statement.

1. Teachers organize online lessons (via Zoom, Skype...) so that they can explain learning content directly. (a)

2. It seems that teachers spend enough time consolidating the subject matter. (a)

3. Teachers try to help my child understand the material better in different ways (extra exercises, videos, photos). (a)

4. It seems that teachers are well prepared for this kind of teaching. (a)

5. The teachers just write down for my child what he has to do in his subject on a certain day/week (R). (a)

6. During remote schooling, it seems that teachers support my child more than in a physical school. (b)

7. The teacher's instructions for home schoolwork are clear and understandable. (b)

8. Teachers monitor my child's work and give him feedback on his work. (b)

9. Communication with teachers is adequate. (b)

10. Teachers are willing to help my child if he needs help. (b)

11. It seems that the scope of learning content is too large. (c)

12. My child spends too much time a day on schoolwork. (c)

13. The tasks my child has to do at home are too demanding. (c)

Note. $\mathrm{a}=$ Online lessons quality, $\mathrm{b}=$ Teacher's remote help to students, $\mathrm{c}=$ Demandingness of online learning

Read the following statements and rate your agreement with them on a scale from 1 to 5 , where 1 means you strongly disagree with the statement, and 5 means you strongly agree with the statement.

1. Online learning could replace physical classroom learning in the future. (a)

2. Remote schooling has enabled my child to perform deep learning. (a)

3. Remote schooling has made my child more independent. (a)

4. When the epidemic is over, classes should continue to be held occasionally (e.g., once a week) in this way. (a)

5. Remote schooling has been a positive experience for me because I learned a lot of new things about the child and myself. (a)

6. Online education will become important in the future. (a)

Note. $\mathrm{a}=$ Parents' views of future prospects and positive experiences with online teaching and learning 


\section{Biographical note}

Melita Puklek Levpušček, $\mathrm{PhD}$, is a full professor of educational psychology at the Faculty of Arts, University of Ljubljana. Her research interests include personal, motivational and social determinants of academic achievement, psychosocial development in adolescence and emerging adulthood and professional development of teachers.

LUKA URŠIČ, MSc, is a school psychologist at Šmartno pod Šmarno goro primary school in Ljubljana. His research interests include the use of ICT and various teaching methods in schools. He is also interested in learning strategies and how to improve the learning process of students. 